IB 1532

.D6 


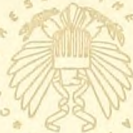

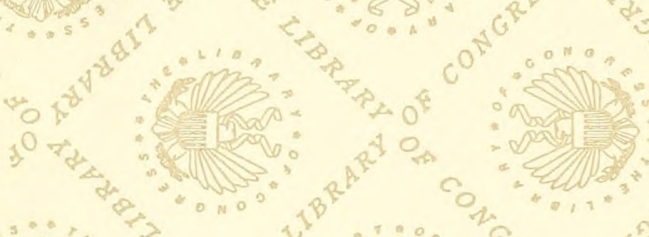

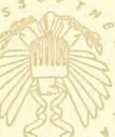

$P_{20}$

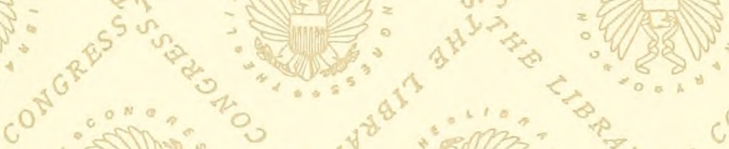
(स) Os

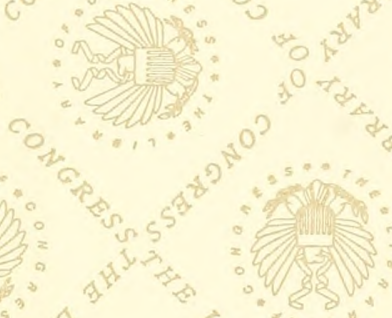

$=0$

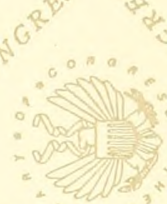

of $1007{ }^{2}=$

(1)

(1)

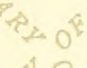

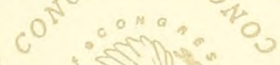

atis

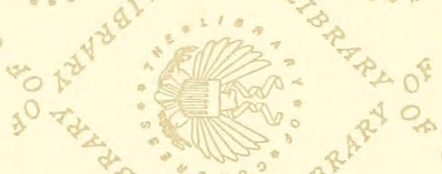

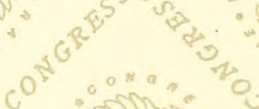

$x=s^{3}-80^{3}$

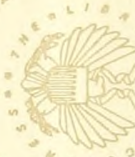

से का

(f)

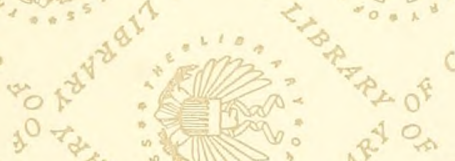

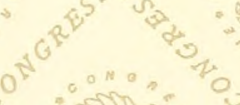

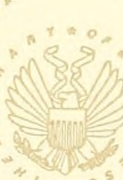

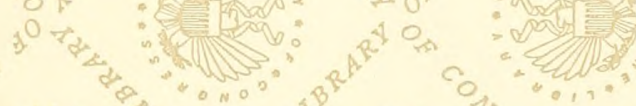

a

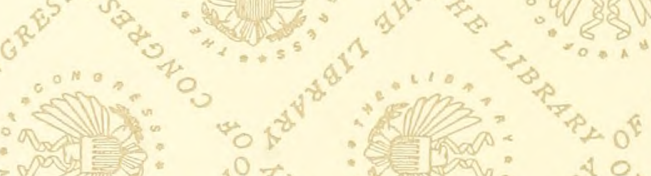
c

$c^{0}=0$ and

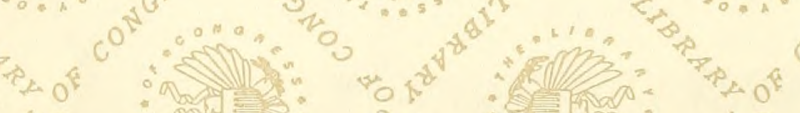
$0^{0.0000}$ 


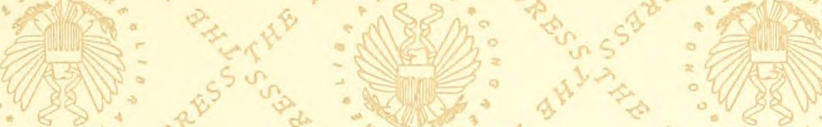
"
$i 0$
$c^{\circ}$
2. Os

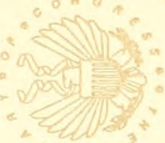

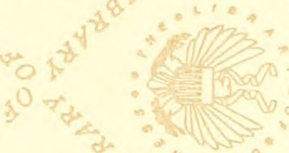
$P$ is 0
(2) os
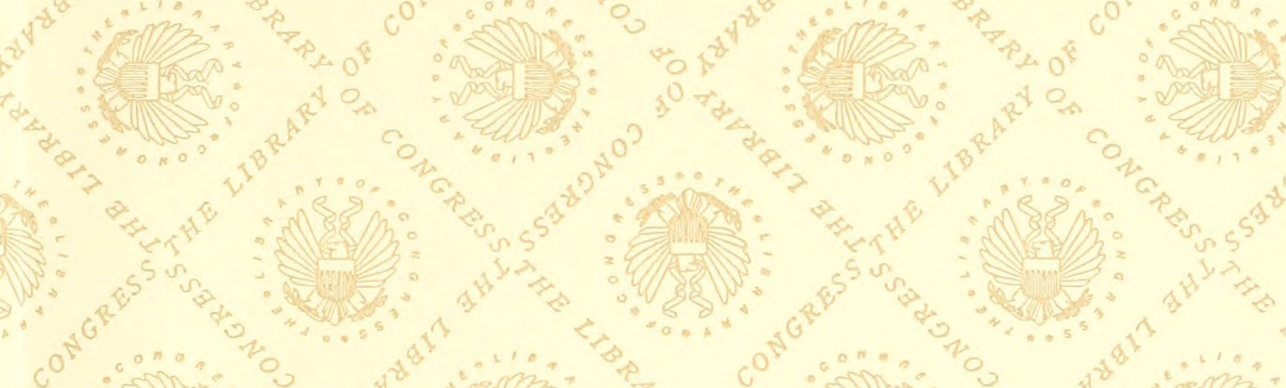

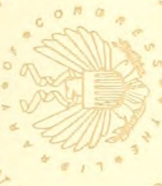

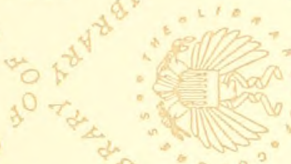
Pिएक

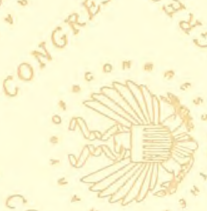

वद्धि,

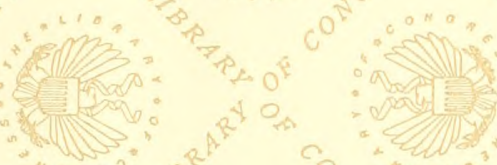
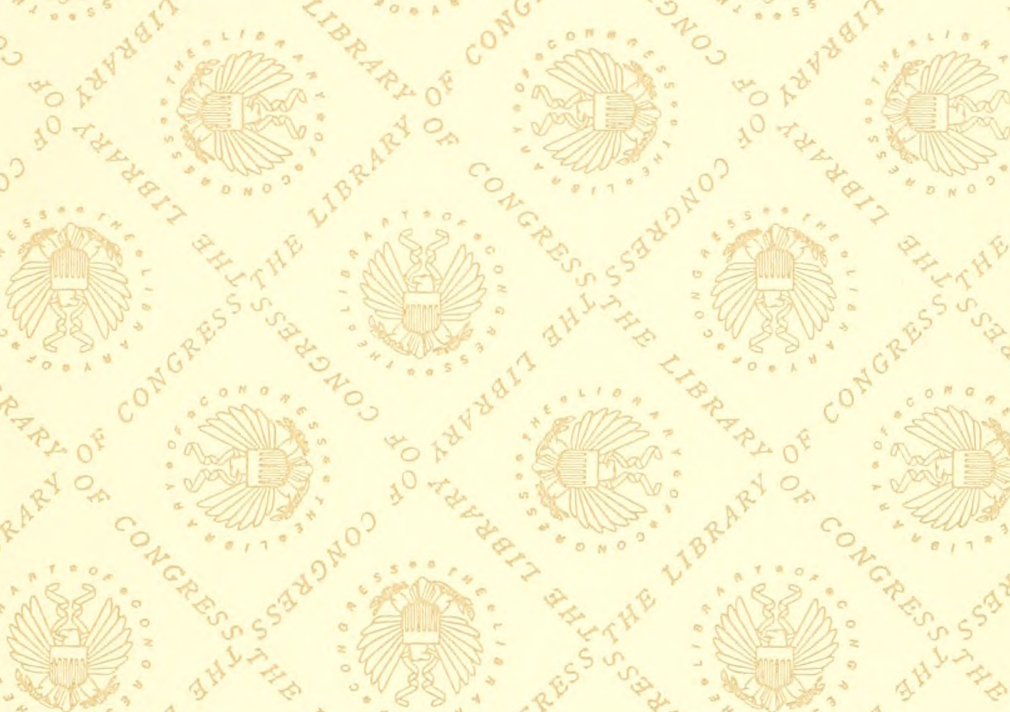

$c^{2}$

ins
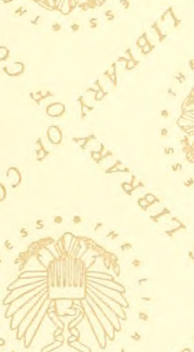

,

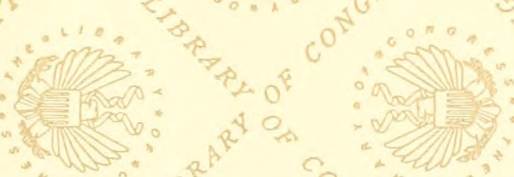

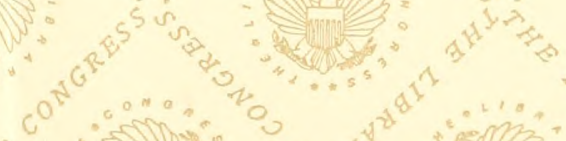
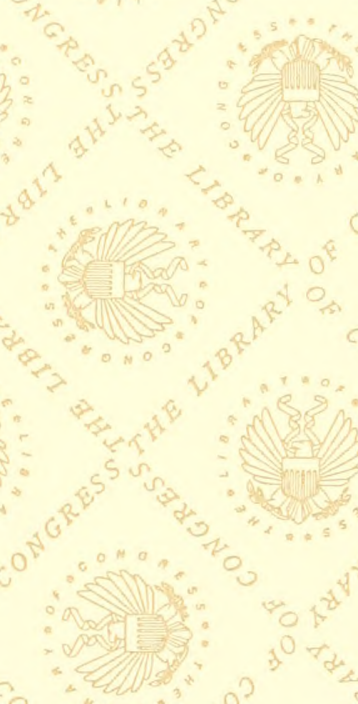

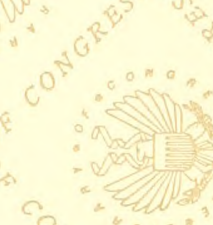







\title{
COURSE OF STUDY
}

NATURE STUDY

AND

\section{ELEMENTARY PHYSICS}

PRIMARY AND INTERMEDIATE GRADES

\section{PUBLIC SCHOOLS}

\author{
OF THE
}

DISTRICT OF COLUMBIA 



\title{
COURSE OF STUDY
}

NATURE STUDY

AND

\section{ELEMENTARY PHYSICS}

PRIMARY AND INTERMEDIATE GRADES

\section{PUBLIC SCHOOLS}

\author{
OF THE
}

DISTRICT OF COLUMBIA 


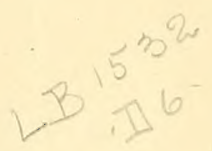

0CT 271909

D. OF D

$\because \vdots$ 
This course of study is the result of a revision and adaptation of the tentative course which has been in use in the elementary schools for the past two years. Acknowledgment is made of the services of the following persons in this revision: S. E. Kramer, Elizabeth V. Brown, H. M. Johnson, Susan B. Sipe, Lulu A. McNally and Edna V. Riddleberger.

A. T. STUART, Superintendent of Schools.

Washington, D. C.,

September I, I909. 



\section{OUTLINE OF NATURE STUDY}

FOR

\section{PRIMARY GRADES.}

\section{FIRST GRADE.}

FIRST TERM.

ANIMALS

Pets: pigeon, canary, cat, dog.

Domestic Animals: cow, horse, sheep.

Aquarium: observation and care.

COMMON FALL FLOWERS

Golden rod and aster, sunflower, morning glory.

Simple plant study-root, stem, leaves, flowers.

FRUITS

apple, grape, pumpkin, nuts.

SEEDS

flying seeds: milkweed and dandelion.

\section{LEAVES}

Study of form and color.

\section{TREES}

Simple study of neighborhood tree; the Christmas tree. 


\section{SEASONS}

Autumn, Winter: months in each season: observation of daily phenomena in autumn and winter; keeping of calendar; migration of birds.

GARDEN

See garden outline.

\section{SECOND TERM.}

\section{ANIMALS}

squirrel, rabbit, mouse.

\section{SIGNS OF SPRING}

observation and discussion.

\section{BIRDS}

hen, duck, robin, bluebird.

\section{TREE}

Continue observation of neighborhood tree-watch swelling and development of buds.

COMMON SPRING FLOWERS

violet, dandelion, daisy, buttercup.

\section{FRUIT BLOSSOMS}

apple, peach, cherry.

\section{SEASONS}

Spring, summer; months in each season, observation of daily phenomena; keeping of calendar; return of birds.

\section{GARDEN}

See garden outline. 


\section{SECOND GRADE.}

\section{FIRST TERM.}

SEASONAL WORK

Autumn, winter. General observation of season's changes in weather, length of days, habits of animals, plants and people.

\section{FALL FLOWERS}

Common garden flowers: purple flowering bean, scarlet runner, cosmos, nasturtium.

\section{FRUIT}

cranberry (in connection with Thanksgiving).

\section{SEEDS}

Tramp seeds, cockle bur, burdock, stick-tight, (review flying seeds).

BIRDS

turkey, meadow lark, cardinal.

\section{TREES}

Recognition of a few common trees; oak, elm, maple. Particular observation of neighborhood tree.

Simple study of pine tree.

Study of the grasshopper.

Animals and plants of special importance in life of primitive people as Indians, Eskimos, Shepherds.
Indian corn
sheep
camel
polar bear
Eskimo dog 


\section{GARDEN}

See garden outline.

\section{SECOND TERM.}

\section{SEASONAL WORK}

Spring, summer. Signs of spring; awakening of nature, return of birds, swelling of buds, changes in neighborhoor tree.

ANIMALS

snail, turtle, frogs.

INSECTS

wasps.

BIRDS

crow, sparrow. Recognition of birds common to locality.

COMMON SPRING FLOWERS

Study bluet, Jack-in-the-pulpit.

BUDS

pussy willow, poplar, horse chestnut:

\section{SEEDLING}

bean.

Plant and animal life related to the study of Robinson Crusoe.

Seasons on the island.

Comparison with our garden.

Study goat. 


\section{THIRD GRADE.}

\section{FIRST TERM.}

\section{LIFE OF THE SEA}

Use when possible the child's vacation experiences. shells, coral, sponge.

\section{STUDY OF VINES}

Using Virginia creeper, ivy, grape, clematis, and morning glory as types. Children should be taught to recognize poison ivy, and warned of its dangers.

STUDY OF THERMOMETER

Weather observation, winds, clouds, sunshine. Effect of temperature, seasonal variations noted; reasons.

TREES

Recognition of a few common trees by leaf and general characteristics; maple, oak, elm, poplar, horse-chestnut. In connection with Christmas study pine and fir.

\section{DISSEMINATION OF SEEDS}

Why seeds travel-agencies.

Children make collection of various kinds of seeds.

\section{CATERPILLARS}

Children should bring collections of cocoons into schoolrooms.

\section{BIRDS}

homes, habits, adaptation of parts, hawks, owl, heron, sandpiper, king-fisher. 


\section{ANIMALS}

beaver, fox.

Continue observation of seasonal changes, correlate with geography work in zones, climatic belt, etc.

\section{SECOND TERM.}

\section{BIRDS IN WINTER}

Protection and development.

\section{PLANTS}

Study a few plants to give children idea how the world supplies our simplest needs-sugar, tea, rice, cotton, flax.

GERMINATION OF SEEDS

pea, bean, squash.

\section{BIRDS}

flicker, red-headed woodpecker, oriole.

TOAD

Life history of the toad, and his work in the garden.

\section{INSECTS}

spiders, ants, crickets, bees.

\section{FLOWERS}

Recognition of common spring flowers; clover study. The study of clover in relation to the life of the bee.

Continue seasonal work. Children observe signs of spring in awakening of all nature. 


\section{FOURTH GRADE. \\ FIRST TERM.}

\section{FLOWERS}

wild carrot, zinnia.

\section{BEETLES}

potato bug, lady-bug, fire-fly.

MOTHS and butterflies in general.

\section{FLESHY ROOTS}

turnip, carrot, radish.

\section{TREES}

Recognition of common trees by leaf and general characteristics, maple, oak, elm, poplar, sycamore, horse-chestnut, linden, locust.

In connection with Christmas; fir, spruce, hemlock.

Study mistletoe and holly.

\section{GRAINS}

corn, wheat, oats; by-products of each, methods of milling, etc.

\section{SHELL FISH}

Study of clam and oyster.

\section{BIRDS}

snowbird, chick-a-dee.

\section{GARDEN}

See garden outline.

Seasonal changes noted in migration of birds; formation of winter buds. Keeping of simple weather moods, includ- 
ing temperature, direction of wind and varying length of night and day.

SPECIAL TOPIC FOR GRADE 4A.

Work of water; evaporation and condensation; forms of . water; water dust, fog, mist, clouds, frost, ice, snow, dew, rain. Work of water in soil making and in shaping the land.

\section{SECOND TERM.}

\section{PLANTS}

sugar maple, Georgia pine, cocoanut, rubber tree, byproducts of each, methods of manufacture, etc.

Study earthworm and mole in relation to garden.

TWIGS

lilac, horse chestnut, poplar, willow, alder, maple, forsythia, fruit buds. Children watch development of buds in classroom for comparison.

BIRDS

Recognition of birds common to locality.

Study purple grackle, thrush, song sparrow.

\section{INSECTS}

Study house fly. In this connection study other household pests as roaches, mosquitoes, bed bugs, moths, etc., to im press lessons of sanitation.

\section{FLOWERS}

Common spring flowers of country and city parks. Recognition of those brought into classroom. Study several. Seasonal changes noted.

\section{GARDEN}

See garden outline. 


\section{Garden Outline.}

\section{FIRST GRADE.}

\section{FIRST TERM.}

Shortly after opening of school familiarize the children with the garden. Teach how and by whom it has been planted and cared for; the part each grade has in it and the necessity for the newcomers to be careful of the rights of others. First grade children are not too young to understand property rights. Extend this to the protection of adjacent private yards.

Language lessons on the beatty of the garden and its value in neighborhood improvement. Correlate color work by finding all the red flowers, the yellow ones, etc. Teach names of three of the commonest plants. Classify plants in garden as vines, shrubs and low growing plants. Note that there are fruits in the garden.

Bulb planting:

\section{Outcloors-}

Observe preparation of soil by older pupils; names of tools: spade, rake, trowel, garden line. Individual planting of bulbs in conformity with sheme of buileling planting: coverine the bed for the winter with stable manure.

\section{Indoors-}

To have succession of bloom, plant bulbs at intervals of two weeks either in soil, manure and sphagnum or stones and water. No detailed study of the bulb should be given in this grade. Note the beauty and fragrance of flowers when they appear. Children should be given entire charge of bulbs and potted plants. Under guidance they should water the plants and keep leaves clean. 


\section{SECOND TERM.}

Germination work in this grade should be conducted wholly by observation and informal talks on the changes involved, omitting formal study as conducted in the past. It should bear on the outdoor work, the grade garden and the home garden. Prepare soil for box which is to be used as miniature garden. Plant varieties of seeds that have been purchased by the children for their home gardens. Plant in rows, labeling each row to aid in identification of the seedlings. Base simple language lessons on observations made, leading children to discover that the plant comes from the seed; some bring the seedcoat above ground, others do not; some have one leaf at first, others two, etc.

Grade assignment for school garden:

Nasturtium and choice of scarlet runner and purple flowering bean. One half of school may plant nasturtium, the other half the bean, if so desired. Start seeds early indoors for transplanting to garden when season permits. An earlier and more orderly garden is thus obtained.

During the interval between planting indoors and transplanting to garden, emphasize the preparation of the home plot by the children, withholding from pupils the seeds purchased until weather permits and the ground is prepared. Perform the following experiments :

I. Plant seeds of the same kind in each of three pots. Place No. I in the cold. Do not water No. 2. Give No. 3 normal conditions. Cover several of the same kind of seed with a half inch coat of clay. Plant in same manner as the rest and treat as No. 3. Conclusion:-Seeds need water, heat and air.

II. Plant small seeds, radish, at different depths in a fiveinch pot, labeling the depth of each. Plant large seeds in same manner. Conclusion:-Large seeds should be planted deeper than small ones. Seeds may be planted so deep they will never come up. 
III. Two growing plants, geraniums, for example, in which the earth is of equal dryness at the beginning of the experiment. Sprinkle one plant with a watering pot as a child is apt to do. Pour water carefully around the roots of the other. After the water has entered the soil, take both plants from the pots and note the depth to which the water has penetrated. Conclusion:-One thorough watering at the roots is much better than several sprinklings.

Systematic watering; weeding and cultivating of the grade garden. Teachers and pupils should have the same pride in an orderly garden that they do in a well-kept schoolroom. Emphasize same for home gardens.

Complete work of the fall with bulbs by language lessons on the plants in bloom and later care of bulbs. 


\section{SECOND GRADE.}

\section{FIRST TERM.}

Follow instructions given under first grade for ethical train. ing. Be persistent in this teaching throughout the year, including the school yard and the yards in the neighborhood.

Visit the grade garden planted by children the previous spring. Put it in good order, training the vines, weeding, etc. Note the effect of the summer on the heans and nasturtiums; the insects that have been destructive; the weeds that grow in this section of the garden. Teach ragweed and plantain.

Complete the cycle of nasturtium and bean from the planting in the spring to the fruit in the fall. Throughout the fall have flowers from grade garden picked. Direct arrangement of them in bouquets to cultivate artistic sense. Collect nastur. tiums and bean sceds. Preserve seeds until spring for the first grade or to be taken home for the home garden.

\section{Bulb planting:}

See directions for first grade. Encourage home planting of bulbs, noting caution given under seed planting in first grade, that the ground must be prepared before the bulbs are taken home. This avoids much waste of material. Nake paper cutting of tools used and the activities of planting. Stories of Holland, the land of the bulbs. Care of window plants and bulbs during the winter.

\section{SECOND TERM.}

Review experiments of first grade to emphasize principles of plant growth.

Bean and squash for germination study. Children of this grade are capable of more detailed germination lessons. 
Grade assignment for school garden:

Balloon vine, and either four o'clock or petunia. Start seeds indoors for transplanting to garden when season permits. Emphasize preparation of soil and the need of fertilizer. Review weeds of first grade. Add purslane, dandelion and pepper grass. Relate surface measurement work to weeding the school lawn.

Complete bulb work of fall with lessons on the blooming plants; care of bulbs.

Home Gardens. 


\section{THIRD GRADE.}

\section{FIRST TERM.}

Visit second grade garden shortly after opening of school to note the effect of the summer. Train vines and weed garden. Make collection of weeds, gathering entire plant root, stem, leaves, flowers, fruit. Dry for review; note adaptations for dissemination and struggle for life.

Review planting of seeds in the spring and complete the cycle of the balloon vine and other seed planted. Collect, label and preserve seeds for next year for second grade.

Teach incidentally petals, calyx or cup; rub pollen on fingers; taste nectar in spurred flower. such as nasturtium or honeysuckle. Do not teach pollination.

Bulb planting outdoors and for indoor forcing. Encourage home planting, noting directions under second grade.

Window culture:

Cuttings of geranium, petunia, wandering Jew, rooted in sand to be transplanted to window box. Care of potted plants and boxes under teacher's guidance throughout the year.

Soils :

Clay, sand, loam, wood's earth or leaf mold. Qualities easily observed in each.

\section{SECOND TERM.}

Cuttings from geraniums, petunia or wandering Jew rooted in sand, to be transplanted to garden in season.

Germination study:

Pea, bean, squash studied by comparison. Bring plants to maturity, showing purpose of flower to produce seed. 
Grade assignment for school garden:

Marigold or zinnia. Plant early in boxes indoors for transplanting in season.

Review principles of plant culture taught by experiment in the second and third grades. Plant seedlings in clay, sand, soil from garden, soil from garden mixing one-third manure. Make application of results to school and home gardens.

Soil worker-Ant.

The gardener's aid--Toad.

Review parts of flower teaching terms, corolla, calyx, stamens, pistil, using fruit blossoms or sweet peas. Bees as pollen gatherers.

Weeds :

Children should be thoroughly acquainted with rag weed, lamb's quarter, curly dock, plantain, purslane, pepper grass, dandelion. 


\section{FOURTH GRADE.}

\section{Fall.}

Visit garden and perform necessary work as directed under first and second grades. Emphasize protection of school and neighborhood gardens. Garden in its relation to civic improvement. Arrange bouquets of garden and wild flowers for the schoolroom. Study vines of the garden: their methods of climbing, comparative value as fence and wall covers. Collect seeds, label and preserve for the grade below.

Review parts of flower, discussing simply the necessity for pollination. Complete cycle of marigold or zinnia planted by children in the spring. Teach that they are collections of many little flowers. Find other flowers, wild ones especially, like them-(aster, goldenrod, dandelion and all members of a composite family).

Pot plants from the garden for the school room. (This necessitates a knowledge on the part of the teacher of potting soils and method of potting.) Bulb planting outdoors and for indoor forcing.

Soils :

Experiments :

I. Page 382 in Nature Study and Life, by Hodge-Use instead of soils suggested in this experiment, clay, sand, clay and manure or leaf mold, sand and manure or leaf mold. Note the effect upon the water retaining power of soils of mixing manure or leaf mold with heavy or light soils.

II. Two flower pots of moist soil filled to within one inch of top. Pack surface firmly; keep top soil of other loose for a half inch in depth. Weigh from day to day. Note the effect of keeping top soil loose upon the amount of water held in the soil.

Watch the action of ice and frost on soil. 
Food storage:

Carrot, radish, turnip, tulip or hyacinth bulb. Plant carrot or turnip in schoolroom toward spring to note its development the second year.

\section{Spring.}

Soil workers:

Earth worm, mole.

Germination :

Pea, bean and morning glory by comparison, emphasizing stored food and its location.

Grade assignment for garden :

Scarlet sage. Plant early in boxes indoors for transplanting to garden later.

Cuttings :

Root cuttings of willow, forsythia or ivy in sand, either for the school or home garden.

Simple experiments to observe the relation of light to plants. Note the effect upon the size of the plant and its color. Apply to selection of desirable places for planting.

Home Garden. 


\section{OUTLINE OF NATURE STUDY}

FOR

\section{INTERMEDIATE GRADES.}

\section{GENERAL DIRECTIONS.}

If careful attention is paid to material it will not be difficult to cover the ground of the following course of study in the time assigned. Material should be present for daily observation and always in good condition. The weekly assignment of time should be devoted to inferences and classification by children. Children should be guided along right lines of observation. There is no subject better adapted to development of independent thinking than nature study. The presence of material is, however, an absolute requisite for thought development. It is better to omit the work entirely than to teach without material. Endeavor to make the school garden furnish much of the nature material. A grade assignment for planting has been given for spring, and the teacher of the grade to which the children are promoted in the fall will complete the life cycle of the plant. This assignment in no way interferes with the school garden. Conferences between teachers and principals of buildings will result in well planned garden and an abundance of material. Real carefully Part I, Nature Study, F. L. Holtz, paying especial attention to Chaps. 4 and 5 . 


\section{FIFTH GRADE.}

\section{Fall.}

Immediately after the opening of school visit the school garden to note the effect of the summer on the part planted by the children the previous spring. Train vines, weed and put in order. This should lead to talk on civic improvement, property rights.

Conplete life cycle of seeds planted by children in the spring, collecting the seeds to be passed to the grade below for use in the spring.

\section{WEEDS}

Review those taught in $3 \mathrm{~d}$ and 4 th grades.

(I) Teach cocklebur, burdock, amaranth.

(2) Life cycle of the dandelion.

Note adaptation of all parts to the plant's struggle for existence in its environment.

Encourage children to make independent observations of the adaptations of other weeds. Collections of weeds will aid them in such study and serve for review. The entire plant should be taken for such specimens.

\section{References.}

(I) U. S. Dept. of Agriculture-Weeds and How to Kill Them, L. H. Dewey. Weeds of Our Cities, L. H. Dewey.

(2) Nature Study and the Child, C. B. Scott.

\section{VINES}

Review those taught in $3^{\mathrm{d}}$ and $4^{\text {th }}$ grades and familiarize children with all the vines of the school garden. They should know at least ten common vines by name and the 
practical value of each around the home or school, together with the following:

Methods of climbing used to reach the light.

Position of leaves in relation to light.

Modes of propagation of vines.

Means of dissemination of fruit.

References--Lessons with Plants-L. H. Bailey. Plant Relations-Coulter. Garden Making-L. H. Bailey.

TREES

(I) Review identification of trees taught in grade below.

(2) Note changes throughout the year in trees taught.

13) Teach white, Carolina, and Lombardy poplar; characteristics; uses of poplar wood; advantages and dis-advantages as city shade trees.

References-

Our Native Trees-Harriet Keeler.

Among Green Trees-Julia E. Rogers.

\section{LEAVES}

Functions (not in detail).

Parts and structure (not minute).

Shapes.

Arrangement for light relations.

Compare arrangement and shapes on different vines, weeds and trees.

\section{INSECTS}

(None of this work should be done in detail. Daily observations of the changes that take place will suffice to arouse interest in the subject. Teach children to be careful to feed the insects brought in with leaves from the plants on which they were found.) 
Life history of butterfly and moth.

Collect caterpillars of milkweed, cabbage butterflies; of cecropia or ailanthus moth. Observe spinning of cocoons. Put cocoons away until spring. In spring when the butterflies and moths emerge note differences between them.

Observations of the outdoor habits of grasshoppers, locusts, crickets, beetles, spiders. Cage some and feed them. Make observations of structure and habits Note similarities and differences.

\section{References-}

Comstock-Manual of Insects.

Holland-The Moth Book.

Holland-The Butterfly Book.

Emerton-Common Spiders.

Hodge-Nature Study and Life.

\section{BULB PLANTING}

Individual planting in school garden. Group planting for winter blooming indoors.

\section{References-}

Garden Magazine.

Holtz-Nature Study.

\section{CARE OF INDOOR PLANTS}

Children should be given complete charge of window plants. Teach proper potting, watering and cleanliness of plants. Encourage this work at home. Discuss with the children artistic appearance of house plants.

References-

House Plants-Hillhouse.

Miniature and Window Gardening-Allen and Godfrey. 


\section{Spring.}

\section{TREES}

Force the growth of branches of the trees assigned for grade study. Study catkins of the poplar by comparison with willow catkins. Discuss wind pollination. Note the opening of the leaf buds. Review spring conditions of all trees taught in lower grades.

BIRD STUDY

Note return of birds-List birds in nearby park or around school if in suburbs. Make individual assign ments of birds such as-English sparrow, grackle, robin. Carry such observations on until end of school. Where it is advisable make bird houses.

References-

Chapman's Birds of N. E. America.

Blanchan-Bird Neighbors.

“ Game Birds.

" How to Attract Birds.

Maynard-Birds of the District of Columbia.

\section{GERMINATION}

Study ways different seeds germinate. Germinate them on blotting paper, in sawdust, under glass or in soil. Use pea, squash, lima bean, onion, four o'clock, corn, sunflower, radish. Note seed leaves of the growing seedlings. Cut them from a bean seedling. Note result. Infer that they are the storehouse of food for the seedling. Note the root hairs or absorption roots. It is well to use the seeds bought by the children for home gardens, so they may have some idea of their vitality and be able to recognize the seedlings as they appear. 


\section{FLOWER STUDY}

Material suitable-fruit blossoms.

Parts of a flower; value of each part in the life history of the plant; similarities and differences between peach and plum; apple and pear.

Carefully bring out the necessity for pollination. Insects as friends to flowers. Flower devices for attracting them.

Wild flowers.

Keep wild flower calendar. Encourage preservation of the wild flowers.

\section{GARDEN WORK}

Propagation of plants by cuttings. Geraniums that have been in the house all winter, chrysanthemums just beginning to sprout; coleus, ivy, are all suitable for sucis work.

Root in box of sand in schoolroom. Transplant to garden or home when rooted.

Grade assignment-

China pink or nasturtium.

Scarlet runner or purple flowering bean.

Sow seeds early indoors. A more orderly garden is thus obtained and much time gained. Transplant to garden when weather permits.

Encourage home gardens. 


\section{SIXTH GRADE.}

Fall.

Teachers should familiarize themselves with the work of the grades below and should keep such information in constant review. The first work of the grade should be a visit to the garden planted by the children the previous spring. Follow instructions given to fifth grade teachers. Complete life cycle of China pink and scarlet runner, the seeds of which were planted by children in the fifth grade. While doing so review the parts of a flower, pollination, insect and flower relations.

\section{SEED DISPERSAL}

Collect fruits and seeds of all kinds.

Differentiate between fruit and seeds.

Classify according to agents of dispersal.

Why fruits are furnished with sweetness, odor, and color.

Encourage independent observations of seed dispersal, using notebooks and drawings to fix forms vividly in mind, not so much for class work as for independent outside work.

\section{References- \\ Seed Travelers-C. M. Weed. \\ Lessons in Botany-L. H. Bailey. \\ Seed Dispersal-Beal.}

\section{TREES}

Review trees taught in grades below.

Teach maples.

Characteristics of all maples.

Distinguish by shape of tree, leaves, buds, fruit, flowers in the spring, the silver maple, red, sugar, sycamore, ashleaved and Norway maples.

Value of wood; as shade trees. 


\section{INSECTS}

Household insects emphasizing sanitary conditions necessary

to prevent house fly and mosquito. Hodge-Nature Study and Life.

\section{BULB PLANTING}

Read and follow directions given to 5 th grade.

\section{INDOOR PLANTS}

Read and follow directions given to 5 th grade.

\section{SOIL STUDY}

Begin a mineral collection. Collect pebbles. Why are they round? What is soil? How is it made? Treat broadly the agents active in soil formation following suggestions in Principles of Agriculture, Chap. I, L. H. Bailey. Learn to recognize typical granite, limestonc, sandstone, shale and gneiss. Make simple observations of granite. Note bleached appearance on outside as compared with freshly broken pieces. Note evidences of action of weather. (Note:-There are many places along Rock Creek and Broad Branch where every stage of the granitic disintegration may be obtained from the solid rock to the powdered soil. This may be sifted by the children to show the different stages. The pebbles afford opportunity to compare those formed by weather action with water worn ones.) What are the forces of weathering? Show composite nature of granite (quartz, mica, feldspar). Clay comes from feldspar, sand from quartz. Composition of garden loam. (Clay, sand and humus.) Is the school soil a sandy loam or a clay loam? Following experiment in Hodge, page 382 , add sand to a handful of the school yard soil. Add clay. Add manure. What is the effect upon the water holding power of the soil? Value of mulchnng the soil. Is the school yąrd soil acid? Test with 
litmus paper. Effect of lime on the soil. Proper method of watering plants. Value of the earth worm.

References-

Hodge-Nature Study and Life, Chap. 23.

Gage-The Great World's Farm.

King-The Soil.

Goodrich-First Book of Farming.

\section{Spring.}

This work should be done wholly by experiments. As experiments require time they should be started the last of February or early March so that the lessons learned may be of value to the spring garden.

\section{PRINCIPLES OF PLANT GROWTH}

I. Absorptive power of roots.

Fill a small vial to brim with water, and another with sugar and water. Cover tightly with a piece of bladder or parchment. Put the one containing water into a glass filled with sugar and water; the one containing sugar and water into a glass of water. This is an excellent illustration of osmosis. The principle upon which it works is explained in any good botany or physics and shows well how the root tip absorbs water.

Lessons to be learned-Plants must not be given food that is too strong. Weeds and grass may be killed by such method but care should be taken in doing so or the effect will be such as results when the salt water from an ice cream freezer touches the grass.

II. Transpiration from leaves.

Simple experiment illustrated in Coulter. 
III. Observe sap in stem. Talk of the same rising in the trees due partly to transpiration and osmosis.

II: Grow plants in dark to show their light relations.

1. Test for starch in green parts of leaf. Use variegated leaves. Test plants grown in dark for same. Simple directions given in Coulter's and Bailey's botanies. Emphasize the value of the leaf as a starch former. Without leaves the ordinary plant would starve.

VI. By simple experiments show that both animals and plants throw off $\mathrm{C}_{2}$ as a waste product. Dispel the theory that plants are harmful in a sleeping room from giving off $\mathrm{C} \mathrm{O}_{2}$.

VII. Perform simple experiments to show the properties of oxygen and $\mathrm{CO}_{2}$. Need of oxygen for combustion and oxidation. Effect of $\mathrm{C}_{2}$ on flame; on life. Test $\mathrm{CO}_{2}$ with lime water. Test breath for $\mathrm{CO}_{2}$. Connect with physiology.

If this work is done wholly by experiment it is not too difficult for a sixth grade pupil. The caution must be given not to make it too technical.

References-

Plant and Animal Life--Snyder.

Coulter's-Plants.

McDougal-Plant Physiology.

Bulletin 195, O. E. S.-U. S. Dept. of Agriculture, Simple Experiments in Agricultural Chemistry.

Soule and Turpin-Agriculture.

TREES

Force branches of trees assigned for grade study. Note thei: flowering and spring condition. 
Follow suggestions given under $5^{\text {th }}$ grade, making individ. ual assignments different from those of the year before. Song sparrow, red eyed vireo, yellow warbler, catbird, are found throughout the city now and are excellent for observation.

\section{WILD FLOWERS}

- Keep calendar of flowers as they appear. Encourage preservation of wild flowers.

\section{GARDEN WORK}

Propagation of plants by division. Chrysanthemums, golden glow, and phlox are excellent for such lessons. Other plants will be found in the school yards that will be much improved by separation. Take advantage of such to teach the subject, transplanting in an orderly way. If there is material left give it to the children for home planting. Boston ferns and aspidistras that have been growing in the rooms all winter need separation in the spring. Let children do the work.

\section{GRADE ASSIGNMENT IN GARDEN}

Scarlet sage or balsam.

Cypress vine.

Find place in the garden to plant several grains of corn for the fall work of the 7 th grade.

\section{HOME GARDEN}

Encourage the planting of vines. 


\section{SEVENTH GRADE.}

\section{Fall.}

Read and follow instructions given to fifth and sixth grade teachers in reference to an immediate visit to the portion of the garden planted by the children the previous spring.

Complete life cycle of at least one of the plants planted by the children in the spring, reviewing the parts of the flower pollination and the relation of flowers and insects taught in fifth grade. The cypress will afford the opportunity to review the subject of vines and the balsam the subject of seed dissemination.

\section{TREES}

Review the identification of trees taught in grades below. Teach OAKS, classify them into groups of black and white oaks, using for such classification the difference in lobes of leaves and position of acorns. There are too many varieties of oaks in this locality to do this work otherwise than very broadly. Children should know pin oak, white oak, and red oak as they are planted on many of the city streets. Leaf fall-reasons for; preparation; cause of fall coloration.

List trees acording to fall colors.

Observe the presence of buds for the coming spring.

Study the life of a tree, applying principles of absorption, transpiration, flow of sap, light relation, starch formation, flowering, pollination, fruit, seed dispersal, yearly growth of stem, twigs, winter buds, enemies, fungus, insects, parasitic growths, etc. It is suggested that one tree should be studied, allowing the study to extend throughout the year and making use of the work taught in lower grades.

Reference-

Among Green Trees-J. E. Rogers. 


\section{GRAINS}

Connect this work with the lessons in cooking.

Familiarize children with stalks of wheat, rye, oats, Study corn in detail. Where practical the sixth grades planted a small quantity of corn. Use the growing corn for the following work. If there is none in the school garden, a few stalks may be procured from the country.

\section{CORN PLANT}

Study each part in the relation to its life struggles for existence.

Roots-fibrous and brace.

Stalk-strength in cylindrical stem; value of pith; how the stalk lifts itself after a storm.

Leaves Blade-veining a protection against storms; fullness of edge; "curling" of the corn leaves.

Sheath-additional protection to leaves; rainguard and its value to the sheath.

Flowers-Tassel and ear flower; the wind a pollen carrier. Uses of the various parts of the plant to man and animals. Relate to commercial geography, developing corn industries and centers of such trade.

$$
\begin{aligned}
& \text { Reference- } \\
& \text { Sargent-Corn Plants. }
\end{aligned}
$$

\section{I.SECTS*}

Relation between insects and flowers; mutual benefits, our benefit. Special attention in this grade to the bee. Begin early in the fall to make insect collections, grouping them according to those that eat vegetables; that require shade trees; that are beneficial. Within the year try to complete life history sets of the same to be kept in school. Carefully

* May be omitted if time allowance is not sufficient for entire amount of work outlined. 
regulate the collecting. Make application to school garden wherever the opportunity arises. Insecticides-their preparation, application and effect.

References-

F. L. Holtz-Nature Study.

Hodge-Nature Study and Life.

Morley-Bee People.

". - Butterflies and Bees.

\section{BULB PLANTING}

Refer to 5 th grade for work to be done and references.

INDOOR PLANTS

Refer to $5^{\text {th }}$ grade for work and references.

\section{WINDOW BOX GARDENS}

Make the window box the specialty of the grade. The planting may be done in the fall using the box for indoor decoration during the winter, or in the spring using it for outdoor decoration. The box should be neat, devoid of printing or signs, preferably painted green and thoroughly drained. Children should be familiar with every step of the work and should be encouraged to repeat the operation at home. The best information for material suitable can be gotten from publication by Dept. of Agriculture, Miniature and Window Gardening, Godfrey and Allen, Nature Study, Holtz.

\section{Spring.}

\section{STORAGE OF FOODS}

Connect with work of the cooking school.

Review starch text given in 6th grade. 
Test corn for the presence of starch.

Plant turnip and allow to flower. Note condition of turnip. Plant a few radish seed and allow to go to seed.

Grow corn and lima beans in lamp chimneys as in the lower grades. Note how seed leaves shrivel as the seedlings advance in size. Cut seed leaves from several beans when they are just above the ground and observe the effect. Dig up a kernel of corn just beginning to send its seed leaves above ground and note that it is soft. Soak some corn, cut away most of the food supply without injuring the germ. Plant and observe the results. Study benefits derived from plants by storing food. Study different methods of storing:

in roots-radish, turnip.

in stem-potato, cabbage, cactus, kohlrabi.

in bulbs-tulip, hyacinth, onion.

in corms-crocus.

in seeds.

\section{TREES}

Force branches of trees assigned for grade study. Oaks are somewhat difficult to force. Bring in branches rather late. Note flowering and delicate coloring of young leaves. Teach American elm.

\section{BIRDS}

Review all birds previously studied. Keep bird calenclar. Note nesting, song, food, care of young and other points of interest. List useful and harmful birds.

\section{WILD FLOWERS}

Keep calendar of flowers. Encourage preservation of wild flowers.

\section{GARDEN}

Propagation of plants by buds. Cannas are the best 
material for this though potatoes illustrate the method too. If a beginning is made with a few canna roots, a large quantity of material will be on hand in a few years.

GRADE ASSIGNMENT

Centaurea, cosmos, zinnia or marigolds. 


\section{EIGHTH GRADE.}

Fall.

Read and follow instructions given to fifth and sixth grade teachers in reference to an early visit to the garden to study the effect of the summer upon it and to put it in order.

Complete life cycle of the seeds planted by the children when in seventh grade. All members of the seventh grade assignment are composites. Children should understand meaning of composite flower; its value in furthering pollination and seed dispersal.

\section{TREES}

Review for identification all trees taught in grades below. Pupils leaving the eighth grade should know the common shade trees of the city by shape in summer and winter; their winter buds; the shape of the leaves; their insect enemies and methods of abating such; precautions necessary in pruning trees; tree ordinances peculiar to the city; the city nursery; our historic trees. Teach native evergreeens and the commonest ones found in parks.

Elementary Forestry-Value of forests as regulators of soil water; knotty and clear lumber; natural pruning in a forest; nature's method of perpetuating chestnuts, oaks, hickories, maples, etc.

Encourage children to plant seeds of trees. Our forest resources; U. S. Forest Service; government reservations; lumber companies in forest exploitation; destructive and conservative lumbering; forest schools at home and abroad. Forests of Germany and France compared with U. S. Develop sentiment in favor of forestry.

References-

Our Native Trees-Harriet Keeler. 
Among Green Trees-J. E. Rogers.

Trees in Winter-A. O. Huntington.

Publications of the Forest Service.

\section{GARDENING}

General oversight of garden and such preparation of gardens as cannot be done by lower grades.

Bulb planting--Refer to $5^{\text {th }}$ grade.

Eighth grade pupils should understand propagation of shrubbery and hedge plants by means of cuttings. Material suitable-privet, lilac, willow, forsythia. Strip off leaves; cut into lengths of six inches; tie in bundles and bury in sand for the winter. If kept outdoors watering is not necessary. Cannas planted by 7 th grade pupils should be cared for in the fall by the 8 th grade pupils.

\section{THE LAWN}

Special work for the grade.

Method of making a good lawn; fall work: spring work: care of the lawn. Urge care of lawns at home.

\section{References-}

Lawns and Lawn Making-Scribner.

A reprint from Year Book, Dept. of Agriculture, I897.

L. H. Bailey-Garden Making.

Simple principles of landscape gardening as laid down by $\mathrm{L}$. H. Bailey in Garden Making. Children should observe and report on good and bad examples of landscape art. Emphasize differences between planting in parks and that suitable for homes. Use pictures freely.

Garden Magazine.

Suburban Life.

Country Life in America. 


\section{Spring.}

Review all trees that class was familiar with in fall. This may be done incidentally, having branches in the schoolroom and quickly teviewing in odd moments.

\section{BIRDS}

Review all birds taught in lower grades.

Bird calendar. Encourage interest in bird study. Methods of attracting birds around homes. Encourage membership in Audubon Society. Discourage egg collecting and wearing of plumage. Read game and bird laws. Discuss their purpose. Teach obedience to them.

\section{WILD FLOWERS}

Keep calendar as in grades below. Note family likenesses in following, thuts bringing out the fact that there are plant families:

Crowfoot-buttercup, columbine, hepatica, rue anemone. Rose-plum, cherry, peach, strawberry, cinquefoil, apple, pear, etc.

Pea-sweet pea, locust, Judas tree.

Violet-common, bird's foot, white, yellow.

Mustard-Winter cress or yellow rocket, cabbage, shepherd's purse, dentaria, pepper grass, sweet alyssum, candy tuft.

Specimens mentioned above are the commonest. By inductive teaching let children discover common characteristics of families.

\section{HOME GARDENS}

Emphasize principles of landscape gardening and care of lawns. 


\section{Elementary Physics.}

\section{SIXTH A.}

\section{MATTER}

(a) Definition: "Anything that occupies space."

Derive this definition by showing that it is impossible to make one more specific that will include all known kinds of matter.

Is matter ever invisible? Show experimentally that air, which is invisible, occupies space and thus prove that matter may be invisible.

(b) Forms or states of matter.

Make classification into solids, liquids and gases using earth, ocean and air as types.

Illustrate changes from one state to another by melting and freezing of ice, evaporation and condensation of water and other substances.

Show application of the principles in the formation of rain, snow and ice; moulding and casting of metals. Note that a change of temperature is necessary to effect a change from one state to another.

Compare gases with liquids and solids as to permanency of shape and size.

(c) Properties of matter.

Illustrate some of the physical properties of matter by the examination of common substances, such as glass, wax, whalebone, blotting paper, lead, rubber and chalk.

Show that the diversified uses of matter result from the many different properties which its different forms possess. 


\section{SIXTH B.}

\section{GRAVITATION}

(a) Its commonest applications and the story of its discovery.

(b) Units of measure-compare pound with kilogram.

(c) Law, stated qualitatively.

(d) How the kind of matter or the interposition of substances affects the operation of the law.

(e) Line of direction; the plumbline; its use to the builder.

(f) Center of mass; how determined in regular and irregular homogeneous substances.

(g) Equilibrium; stable, unstable and neutral.

Its application in the construction of sail boats, loading of wagons, etc.

(h) Pendulum; show by simple experiment that the vibration is dependent upon the length and independent of the material used. Show application of principal in construction of a clock.

\section{References-}

Higgins' First Science Book, Chapter I. Avery's Elements of Natural Philosophy. Secs. II, IV.

Woodhill's Simple Experiments in Physics.

Other works on Physics.

Observation Blanks in Physics-American Book Co.

First Coúrse in Physics-Millilken and Gale. Experimental Physics-W. A. Stone. Introduction to Physical Science-Gage. Elements of Physics-Fisher and Patterson. Real Things in Nature-E. S. Holden. 


\section{SEVENTH A.}

\section{FLUID PRESSURE}

(a) Define fluid. Contrast matter in fluid state with matter in solid state and show basis of classification of matter into solids and fluids.

Show further classification of fluids into liquids and gases.

(b) Liquid pressure. Water as type. Compare solids and liquids with respect to their ability to transmit pressure.

Show relation of the downward pressure of both liquids and solids to their weight.

Derive law for transmission of pressure in liquids, experimentally.

Show application of law in the leaky hose, in the lawn fountain, in the hydrostatic press, construction of bridge piers, dams, etc. Show the relation of the different surfaces of a liquid in communicating vessels. Show application of this principle of surface level in liquids in the springs of nature and the city water systems; coffee pot, teakettle, etc.

(c) Buoyancy and floating bodies.

Find the loss of weight of a heavy regular solid immersed in water. How does this loss in weight compare with the weight of a volume of water equal to the volume of the solid? Account for this loss of weight by application of law for transmission of pressure in liquids.

Show application of the principle of buoyancy in the diver's suit.

What happens when the loss of weight equals the weight of the solid? When is it greater than the weight of the solid?

Show application in the construction of ships. 
(d) Atmospheric Pressure.

Air as a type.

I. Show with a simple pressure guage that air as well as water transmits pressure equally in all directions.

2. With a mercury barometer or a lift pump measure an atmospheric pressure.

3. Show application of the principal of the pressure of gases in the air pump, the pop gun, the siphon, force and lift pumps, bicycle and automobile tire. 


\section{SEVENTH B.}

\section{MACHINES}

(a) Lever.

With a yard stick show uses of the lever and the relation between the power and weight and power arm and weight arm.

Derive the law and classification of the lever.

Show application of principle in the crowbar, the well sweep, the bones of the body, shears, nut cracker, hammer, derrick and other machines.

(b) Pulley.

(I) Single fixed pulley.

Show advantages gained by the use of this machine. Ascertain relation between power and weight.

Show application in the hay fork.

(2) Single movable pulley.

Show advantage gained by the use of this machine and relation between power and weight.

Derive law for the single pulley.

Show uses of pulley.

(c) Wheel and axle.

Show relation between power and weight. What advantage is gained by the use of the wheel and axle? Compare the wheel and axle in principle with the lever. Derive law of wheel and axle. Show application in the capstan, pilot wheel and windlass.

Derive general law of machines.

\section{References-}

Higgin's First Science Book, Chap. II, III. Avery's Elements of Natural Philosophy. Woodhill's Simple Experiments in Physics. Other works on Physics. 


\section{EIGHTH A.}

\section{SOUND}

Production, transmission, velocity, reflection, and pith.

(a) Production.

Sound a tuning fork and by means of pith balls or a vessel of water show that the prongs are in a state of vibration.

Illustrate further that sounding bodies are in a state of vibration by the use of piano strings, Jew's-harp, stretched rubber bands, hand bell and graphophone.

(b) Transmission.

Exhaust an air receiver in which is placed an electric bell connected with a battery. As the air becomes rarer note the diminution of sound until finally the bell becomes inandible. What does this prove as to the necessity of a medium between the sounding body and the ear for the transmission of sound ${ }^{3}$ This experiment can be made in the laboratory of any high school. Teachers who are not able to make arrangements to have their classes witness its performance may omit the experiment.

Illustrate by use of the acoustic telephone, by scratching on the ends of long bars of wood and iron and by tapping on the sides of a tub while the ears are under water that solids and liquids are needed for the transmission of sounds as well as gases.

Illustration: The buried miner Hicks communicated with those above ground by means of a metal pipe.

(c) Velocity.

Calculate the velocity of sound per second by noting the time between the flash and the report of a gun, or the escape of steam and the sounding of the 
whistle on a locomotive; the gun and locomotive being at known distances from the observer.

With this velocity ascertained, calculate the distance of a discharge of lightning by noting the time between the flash of lightning and the peal of thunder.

(d) Reflection.

Place a watch in front of the center of a concave reflector, moving it to and from the reflector on the same line until the maximum sound is reached. Note the effect of the reflector on the magnitude of sound.

Further illustrate the reflection of sound by echoes produced by walls, cliffs, surfaces of water, whispering galleries. Call attention to the echoes in the dome of the Capitol and statuary hall.

(e) Pitch.

With two tuning forks of a known number of vibrations each note the difference of pitch.

What is your conclusion of the relation between pitch and the number of vibrations? What is your conclusion of the relation of strings and their vibrations?

HEAT

Sources, temperature, effects, transference. Applications and illustrations.

(a) Sources.

Show experimentally that friction, percussion, compression, chemical action and combustion and the sun are sources of heat.

The following material will supply the necessary apparatus for these experiments: a convex lens or reading glass, file, soft iron nail, hammer, piece of 
sheet iron, a small piece of unslaked lime, a bicycle with pump.

Supplement these experients with other illustrations from the machine shop, the laboratory, or elsewhere, showing the production of heat.

(b) Temperature.

Take three vessels, the first containing water as hot as the hand can bear, the second containing warm water, and the third containing cold water. Put the right hand into the first vessel and the left hand into the third, holding them there for a short time. Then put both into the second vessel and note the effect on both hands. Do both hands indicate the same temperature? Can bodily sensation be relied upon to determine temperature? Repeat the experiment, using two thermometers instead of the hands. Do the thermometers read alike when they are in the second vessel?

Discuss construction, kinds and uses of thermometers.

(c) Effects.

Carefully measure a long iron nail or rod. Heat and measure again. Is it longer or shorter?

Fill a bottle with water and fit a stopper tightly intu its mouth. Heat the water and note the result. Allow both nail and water to cool again and note the result.

What do the experiments show as to the effects of heat on solids and liquids?

Note the application of this principle in the building of guns, bridges, boilers, and the setting of wagon tires, etc.

Exception: Allow a small bottle filled with water to freeze solid. Note the effect.

Illustrate the application of the principle of expansion 
of freezing water in the bursting of the water pipe and the floating of ice.

Ebullition and evaporation. Boil a vessel of water continuously for thirty minutes. Note the effect on the quantity of liquid.

Set the same vessel containing an equal amount of water aside in the room for two weeks. Note again the change in the quantity of liquid.

Pour a little alcohol or ether on the hand and note the effect on the temperature.

Show the application of the principle of slow and -rapid evaporation in the process of distillation, in the formation of rain and the manufacture of ice.

(d) Transference of heat.

Show conductivity of heat by metals and convection by liquids and gases, by simple experiments, using as material iron and copper wire, test tube, water and saw dust. Show application of principle in the boiling of water, heating of buildings, etc.

References-

Higgin's First Science Book, Chapters IV and V. Woodhill's Simple Experiments in Physics. Avery's Natural Philosophy.

Other works on Physics. 


\section{EIGHTH B.}

\section{LIGHT}

Sources, propagation, intensity, reflections, and refactions.

(a) Sources.

Try to see the filament of an incandescent lamp before and after a current of electricity is passed through it. Distinguish between luminous and illuminated bodies. How do you see other objects in the room? Give examples of other luminous bodies.

(b) Propagation.

Admit a ray of sunlight into a darkened room through a small hole in one of the curtains. Distribute chalk dust in its path.

Interpose an opaque screen between the eye and an object. Can you see the object?

What conclusion do you draw from these experiments as to direction of propagation of light?

Place a lighted candle about a yard from a white wall in a darkened room. Between the candle and the wall hold a card containing a small pin hole. Compare the image of the flame on the screen with the flame in position and size.

Bore a hole, about an inch in diameter, in the center of the bottom of a chalk box. Cover the top of the box with oiled white paper. Paste over the opening in the bottom a smooth piece of tinfoil and carefully make a pin hole in the middle of it. Admit the light from a brightly illuminated or luminous body into the box through the small hole in the tinfoil. Discuss the relation of the image and the object as to size and position and distance from the opening in the tinfoil. Discuss application of principle in the eye and the photographic camera. 
(c) Intensity.

Place a screen six inches square midway between a white wall and a lighted candle whose distance from the wall is two feet. The screen should be parallel to the wall. Compare the area of the shadow on the wall with the area of the screen. Repeat the experiment using other distances from the wall for both screen and candle.

The quantity of light that illuminates the screen would illuminate what part of the wall if the screen were removed? Would the illumination of the wall be less or more intense than was the illumination of the screen? Derive law for relation between distance and intensity of illumination.

(d) Reflection.

With a small mirror reflect a beam of light coming into a darkened room through a small opening in the shutter or shade. Trace the path of the incident and reflected ray by means of chalk dust. Compare the angle the incident ray makes with a line perpendicular to the surface of the mirror at the point of contact of the ray of light with the angle the reflected ray makes with the same line. What is the relation between these two angles?

Illustrate the application of this principle in the construction and use of the kaleidoscope, heliograph and heliostat and cause of twilight. Place an object between two parallel mirrors and note the multiplication of images. Explain.

(e) Refraction.

Place a small metallic object in the bottom of a cip or basin and stand so that you can just see over the edges of the vessel. While some one pours water into the vessel observe the apparent change in the position of the object and the depth of the water. 
Make diagram showing path of ray of light from the object to the eye. Harmonize this phenomena with the law for the propagation of light.

Note appearance of a straight stick in a clear body of water. Explain.

With a convex lens, an ordinary reading glass, or one of the lenses from a pair of spectacles will answer, focus on a sheet of paper the light from the sun or a lighted candle. What effect on the direction of the propagation of light has the lens? Examine a page of your book through the lens. Explain.

Discuss illustrations of the principles of refraction of light in the construction and use of the simple microscope, camera, human eye, eyeglass, stereopticon and other optical instruments.

Admit a beam of sunlight into a darkened room, allow it to pass through an ordinary glass prism, and catch the refracted beam on the wall. Note color of bean.

Collect the refracted beam, immediately after it passes through the prism, with a convex lens and note the color of beam.

What conclusion do you draw from these experiments as to the composition of sunlight?

MAGNETISM

Suspend by a silk thread in a paper stirrup a bar magnet. Bring alternately the $\mathrm{N}$ and $\mathrm{S}$ end of another bar magnet to each end of the suspended magnet. Note result and derive law for attraction and repulsion of magnets.

Suspend sewing or knitting needle in the same manner as in the previous experiment and bring each end of a bar magnet to each end of the needle alternately. Is the needle a magnet? 
Now rub the needle from one end to the other several times with the north end of the bar magnet. Again suspending the needle bring each end of the bar magnet to each end of the needle and note its behavior. Is the needle a magnet? Mark its north and south ends. Repeat the experiment with another needle, using the south end of the bar magnet in rubbing the needle. Compare the two suspended needle magnets with relation to their polarity.

Describe method of making a permanent magnet.

Heat one of the needle magnets until red, and when cool test for magnetic properties. Give conclusions as to effect of heat on a magnet. Note the direction in which the suspended magnetic needle lies when it comes to rest. Explain.

Discuss application of the magnetic needle in the compass.

Place a bar magnet on a sheet of paper and cover with iron filings or small tacks. Lift the magnet and observe where the attraction for the iron filings is greatest.

Sprinkle iron filings over a sheet of paper under which is a bar magnet. Tap the paper gently. Notice closely the way the filings arrange themselves. Make a drawing of the arrangement of the filings. Place a small pocket compass in different positions on the paper in the magnetic field and note the direction in which the needle points.

Indicate these directions on your map. Repeat the experiment, using cardboard, wood, and glass instead of paper. Does the force of the magnet act through these substances as well as through paper?

Break a needle magnet and test each part for all the properties of a permanent magnet. Conclusions. 
Use of the magnet in collecting metal substances from bins in the large elevators.

\section{STATIC ELECTRICITY}

Rub a glass rod with a dry silk cloth and immediately bring it near some small bits of paper or a suspended pith ball. Repeat the experiment, using a stick of sealing wax and a woolen cloth in place of the glass rod and silk cloth. Note phenomena it each case. All material used must be dry. The power generated in certain substances by friction of attracting and repelling objects is termed frictionai electricity.

(I) Two kinds of electrification.

Rub a glass rod with silk and suspend it in a stirrup made of a hairpin, by a silk thread.

Electrify another glass rod in the same manner and suspend it so that the ends of both rods are near each other. Is there attraction or repulsion? Was the electrification of both rods the same?

Electrify a glass rod with silk and a stick of sealing wax with flannel and bring their ends near to each in the same manner as in the last experiment. Is there attraction or repulsion between the rods?

Calling the electricity developed with silk on the glass positive, and that developed with the flannel on the sealing wax negative, derive law of attraction and repulsion of electrified bodies.

Repeat the experiment, using other subjects. IIlustrations: Combing the hair, rubbing the hair, rubbing cats' fur, flash of lightning.

The consideration of current electricity is omitted from this course because it is not possible, at this time, to supply the apparatus necessary for such sturly. 


\section{BIBLIOGRAPHY.}

\section{General References.}

A few familiar flowers ........... Margaret Warner Morley According to seasons ........Mrs. Frances Theodora Parsons Agriculture for Beginners ........ Burkett, Storms, and Hill Corn plants, their uses and ways.... Charles Sprague Sargent Familiar trees and their leaves ...Ferdinand Schuyler Mathews From seed to leaf .................. Jane H. Newall

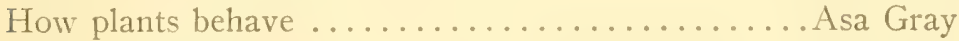

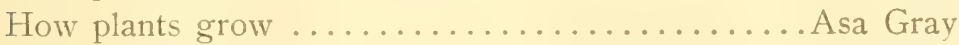
How to know the wild flowers ...... Mrs. William Starr Dana Lessons with plants ................ Liberty Hyde Bailey Little wanderers ..............Margaret Warner Morley

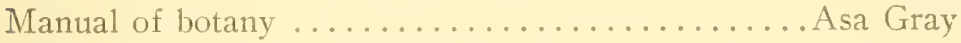

Manual of the trees of North America ..............

Charles Sprague Sargent Nature stories for young readers ........... Florence Bass Nature study and life ........... Clifton Fremont Hodge Nature study and the child .............. Charles B. Scott Nature study in elementary schools

Mrs. Lucy Langdon Wilson Nature's garden .................... Neltje Blanchan Our native trees and how to identify them

Harriet Louise Keeler

Plants and their children ..... Mrs. Frances Theodora Parsons Sea stories for wonder eyes ............Mrs. A. S. Hardy Seed babies ................Margaret Warner Morley Seed dispersal .................William James Beal Seed travelers ...............Clarence Moores Weed Special method in elementary science

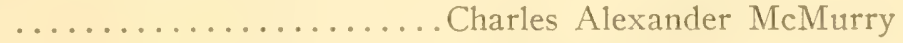
Study of trees in winter ..........Annis Oakes Huntington 
The essentials of botany ............... Charles E. Bessey The fairyland of flowers ..................... Pratt The plant baby and its friends ......... Kate Louise Brown The story of the plants ................. Grant Allen Trees, shrubs and vines .............. E. Parkhurst

Animals.

Cats and $\operatorname{dogs} \ldots \ldots \ldots \ldots \ldots \ldots$. James Johounot Domesticated animals ......... Nathaniel Southgate Shaler Four-footed Americans ............Mabel Osgood Wright Habits and behavior of animals ......... John Burroughs

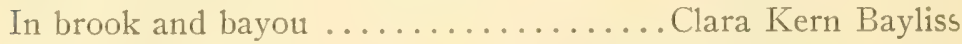
Life and her children .........Mrs. Arabella Burkley Fisher Lives of the hunted ......... Ernest Thompson Seton Our home pets ................ Olive Thorne Miller Squirrels and other fur bearers ...........John Burroughs The kindred of the wild ........... Charles G. D. Roberts Wild beasts ................... J. Hampden Porter Vild neighbors . . . . . . . . . . . . . Ernest Ingerso.1 Wilderness babies .............Julia Augusta Schwartz Winners in life's race Mrs. Arabella Burkley Fisher

Birds.

A charm of birds .................................... Porter

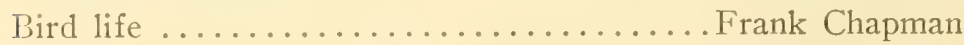

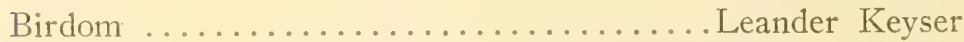
Bird homes ...............Arthur Radclyffe Dugmore Bird ways .......................... Thorne Miller Birds in the bush ............................. Torrey Birds through an opera glass ........... Florence Merriam Citizen bird........Mabel Osgood Wright and Elliott Coues

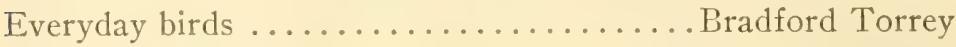
First book of birds ............... Olive Thorne Miller Hawks and owls from the standpoint of a farmer ........ 


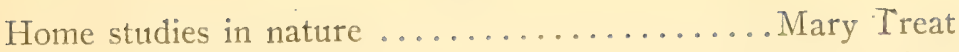

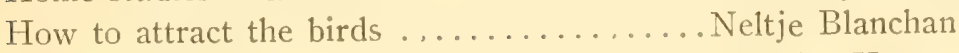
In bird land .................................. Keyser In nesting time ................ Olive Thorne Miller Little brother of the air ............ Olive Thorne Miller Some common birds in their relation to agriculture ...... . Foster Ellenborough Beai Stories of bird life T. Gilbert Pearson

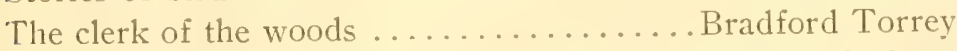
The common crow .............. S. Dept. of Agriculture The woodpeckers .............. Fannie Hardy Eckstorm

\section{Insects.}

Among the moths and butterflies Julia P. Ballard Ants, bees, wasps ............. John Lubbock Avebury Entomology for beginners ......... Alpheus Spring Packard Everyday butterflies ............ Samuel Hubbard Scudder Eye-spy ................William Hamilton Gibson How to keep bees .............. Anna Botsford Cornstock Insect folk .................. Margaret Warner Morley Insect life ................. John Henry Comstock Insects ............... Alpheus Hyatt and J. M. Arms Insects .................. John Lubbock Avebury Life histories of American insects.... Clarence Moores Weed Natural history ...................... J. J. Wood On certain grass-eating insects ......... Ephriam Porterfelt Romance of the insect world ............. N. Badenoch Sharp eyes ..............William Hamilton Gibson Tenants of an old farm ......... Henry Christopher McCook The butterfly book .............William Jacob Holland The hive and the honey bee ...... Lorenzo Lorrain Langstroth The insect world ............... Clarence Moores Weed The life of the bee .............. Maurice Maeterlinck The population of the old pear tree ........... E. Bruyssel Wasps, social and solitary ......... W. and E. G. Peckham 


\section{Gardening.}

Bulletin of the Department of Agriculture, school gardens ........................ C. Corbett Bulletins 160 and 204

Office of Experiment Station, U. S. Dept. of Agriculture (hildren's gardens for school and home. . L onis Klein Miller Flowers of Japan and art of floral arrangement..... J. Condu How to make a vegetable garden ..... Edith Loring Fullerton How to make school gardens ............ H. D. Hemenway Gardening for beginners ................ T. Cook

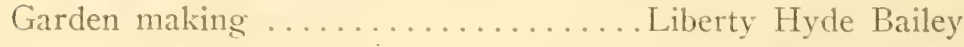
Nature study ................... Frederick L. Holtz School gardening and nature study in English rural schools

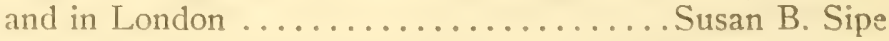









;

$$
\text { 4. } 76791: 4
$$







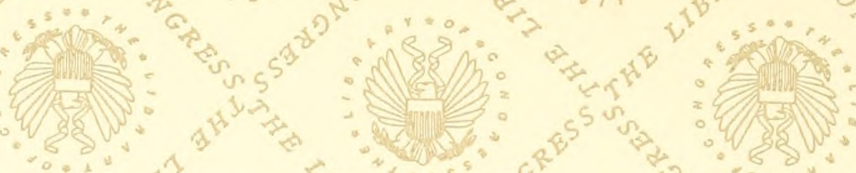

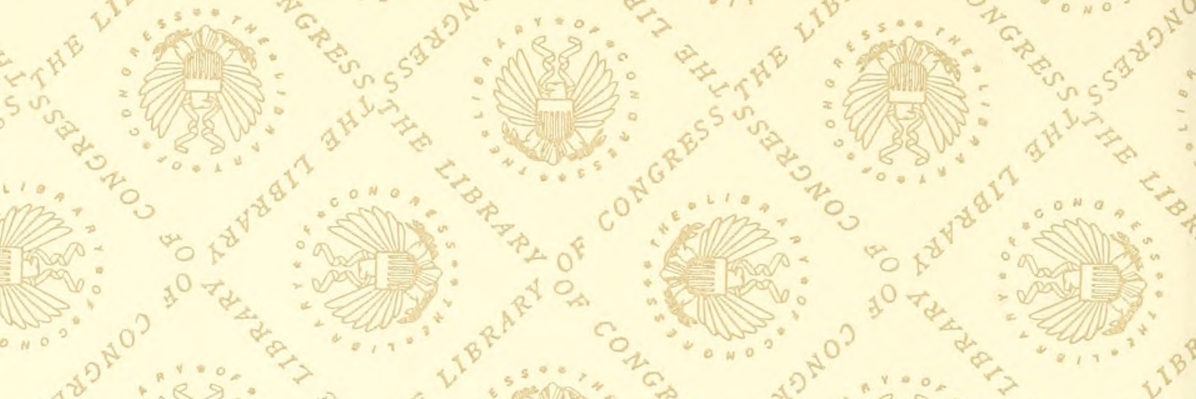

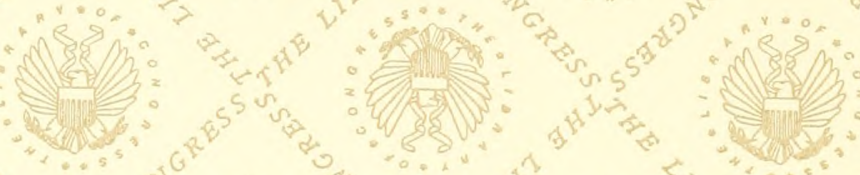

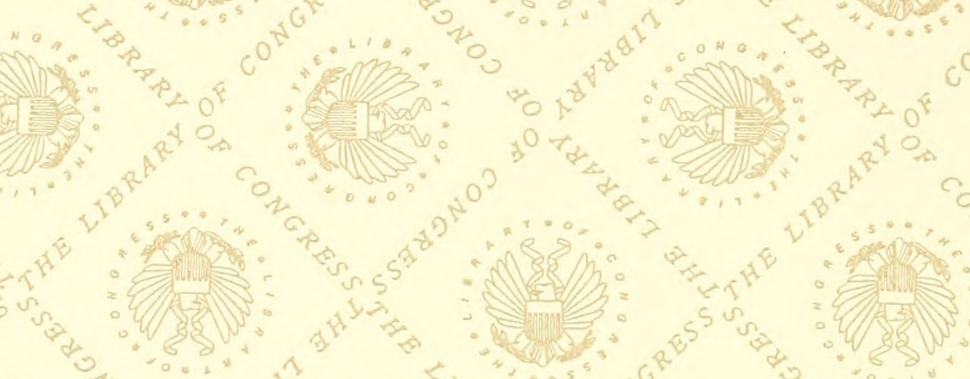

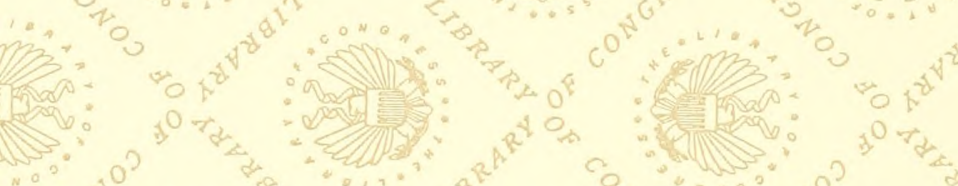

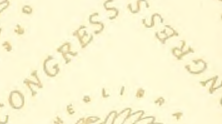

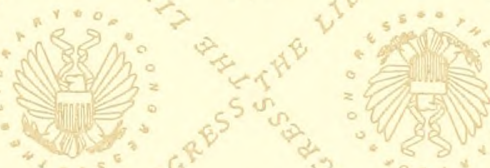

Wist

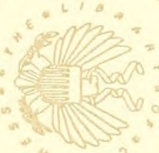

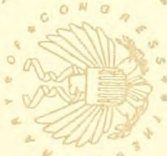

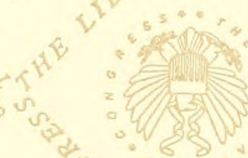

Whes

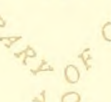

a)

$40 x^{8}$

$x^{0} \nabla_{2}$

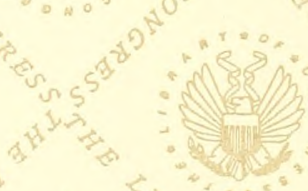

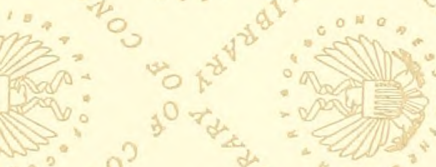

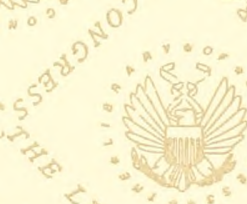

$c^{2}=12+1 / 0$
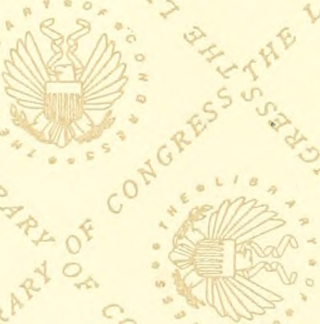

,

ats 


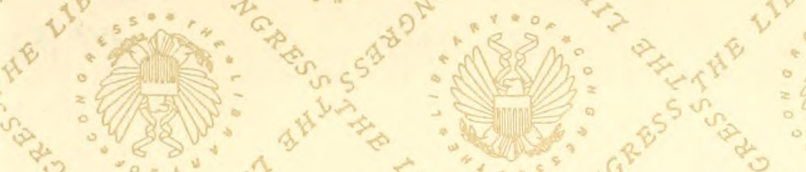

(4)
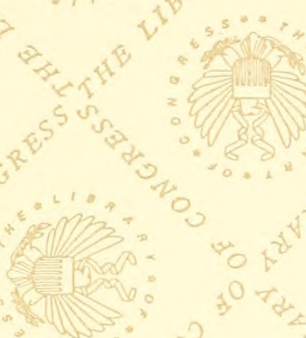
LIBRARY OF CONGRESS

$021763782 \mathrm{~A}$ 